\title{
Guidelines for the use and interpretation of palaeofire reconstructions based on various archives and proxies
}

\author{
Cécile C. Remy ${ }^{\text {a, }}{ }^{*}$, Cécile Fouquemberg ${ }^{\text {a, b }}$, Hugo Asselin ${ }^{\mathrm{b}}$, Benjamin Andrieux ${ }^{\mathrm{b}, \mathrm{c}}$, \\ Gabriel Magnan ${ }^{\mathrm{d}}$, Benoît Brossier ${ }^{\mathrm{a}}$, Pierre Grondin ${ }^{\mathrm{e}}$, Yves Bergeron ${ }^{\mathrm{b}}$, Brigitte Talon ${ }^{\mathrm{f}}$, \\ Martin P. Girardin ${ }^{\mathrm{c}}$, Olivier Blarquez ${ }^{\mathrm{g}}$, Lisa Bajolle ${ }^{\mathrm{a}, \mathrm{b}}$, Adam A. Ali ${ }^{\mathrm{a}, \mathrm{b}}$ \\ a Institut des Sciences de l'Évolution de Montpellier, UMR 5554 CNRS-IRD-Université Montpellier-EPHE, Montpellier, France \\ ${ }^{\mathrm{b}}$ NSERC-UQAT-UQAM Industrial Chair in Sustainable Forest Management, Université du Québec en Abitibi-Témiscamingue, Rouyn-Noranda, QC, Canada \\ c Natural Resources Canada, Canadian Forest Service, Laurentian Forestry Centre, Sainte-Foy, Québec, QC, Canada \\ d GEOTOP Research Center, Université du Québec à Montréal, Montréal, QC, Canada \\ e Ministère des Forêts, de la Faune et des Parcs du Québec, Québec, QC, Canada \\ ${ }^{\mathrm{f}}$ IMBE, Aix Marseille Univ, Univ Avignon, CNRS, IRD, Aix-en-Provence, France \\ ${ }^{g}$ Département de Géographie, Université de Montréal, Montréal, QC, Canada
}

A R T I C L E I N F O

Article history:

Received 13 March 2018

Received in revised form

4 June 2018

Accepted 5 June 2018

Available online 30 June 2018

Keywords:

Wildfire

Palaeoecology

Charcoal

Holocene

Soil

Peat

Lake sediments

Tree rings

\begin{abstract}
A B S T R A C T
We present a comparative analysis of fire reconstructions from tree rings and from wood charcoal preserved in forest soils, peat and lake sediments. Our objective is to highlight the benefits and limits of different archives and proxies to reconstruct fire histories. We propose guidelines to optimize proxy and archive choice in terms of spatial and temporal scales of interest. Comparisons were performed for two sites in the boreal forest of northeastern North America. Compared to others archives, tree-ring analysis remains the best choice to reconstruct recent fires $(<1000$ years). For longer periods (from several centuries to millennia), lake charcoal can be used to reconstruct regional or local fire histories depending on the method used, but the focus should be on historical trends rather than on the identification of individual fire events. Charcoal preserved in peat and soils can be used to identify individual fire, but sometimes cover shorter time periods than lake archives.
\end{abstract}

\section{Introduction}

In the next decades, wildfire activity is projected to increase under global warming in many parts of the world, leading to unprecedented ecological and socioeconomic consequences (Bond et al., 2005; Granström, 2001; Kelly et al., 2016; Stevens-Rumann et al., 2018; Stocks et al., 1998). A better understanding of longterm (centennial to millennial) ecosystem dynamics is necessary to better predict the impacts of global change and to adapt forest management accordingly (Clark et al., 1998; Gavin et al., 2007; Kelly et al., 2013; Robin et al., 2013; Sanborn et al., 2006; Tolonen, 1985). Palaeoecological studies aimed at reconstructing past wildfire

\footnotetext{
* Corresponding author. Institut des Sciences de l'Évolution de Montpellier, UMR 5554 CNRS-IRD-Université Montpellier-EPHE, Montpellier, France

E-mail address: cremy@unm.edu (C.C. Remy).
}

histories are commonly used to complement modern fire statistics by providing an understanding of variability over time and space (Clark et al., 1998; Robin et al., 2013; Sanborn et al., 2006; Tolonen, 1985).

Different proxies are available to reconstruct fire histories, each presenting advantages and shortcomings depending on the information sought (Waito et al., 2015). Thus, all proxies and methods are not necessarily appropriate for all palaeofire reconstructions, depending on the targeted time- and spatial-scale. Microscopic $(<160 \mu \mathrm{m})$ and macroscopic $(>160 \mu \mathrm{m})$ charcoal particles deposited and preserved in forest soil, peat and lake sediments can be used to reconstruct regional (outside the watershed) and local (inside the watershed) fire history, as well as fire scars on trees (Falk et al., 2011; Gardner and Whitlock, 2001; Gavin et al., 2007; Oris et al., 2014a; Tolonen, 1985; Whitlock and Larsen, 2002; Whitlock and Millspaugh, 1996). Tree rings offer inexpensive and high 
resolution (annual) fire reconstructions, but usually record only a few centuries of fire history in most environments (Agee, 1998, 1993; Dieterich and Swetnam, 1984). Furthermore, in areas characterized by high-severity fires, only the date of the last fire can be inferred from the age of the oldest trees, i.e. time of post-fire stand regeneration (Drobyshev et al., 2017; Waito et al., 2015; Wallenius et al., 2015).

Proxies based on charcoal preserved in different archives (soil, peat, lake sediments) are more expensive due to the cost of ${ }^{14} \mathrm{C}$ dating, but cover longer (multi-millennial) time scales (Conedera et al., 2009). However, charcoal production, transport, settling and percolation are dependent on a multitude of environmental variables and taphonomic processes (Conedera et al., 2009; Whitlock and Larsen, 2002). Charcoal preserved in forest soils are not stratified, and the reconstruction of fire histories using this archive requires even more ${ }^{14} \mathrm{C}$ dates compared to lake and peatland archives which are composed of stratified sediments (Carcaillet et al., 2001; Gavin et al., 2003). Moreover, charcoal particles preserved in peat and soils can be destroyed by re-burning during subsequent high-severity fires (Lertzman et al., 2002; Ouarmim et al., 2015), thus inducing a loss of information over time. Finally, peatlands are less susceptible to deep burning than forest soils owing to their high moisture content (Terrier et al., 2014) and hence, charcoal preserved in peat layers under waterlogged conditions can be protected from post-deposition combustion.

Although charcoal in lake sediments are not subjected to reburning, they include signals from both regional and local fire events (i.e., from outside and within the watershed) in contrast with large charcoal particles $(>0.5-2 \mathrm{~mm})$ from soil and peat deposits which are local in origin (Asselin and Payette, 2005a; Conedera et al., 2009; Ohlson and Tryterud, 2000; Tolonen, 1985). Charcoal particles larger than $160 \mu \mathrm{m}$ found in lake sediments can be used to reconstruct fire events that have occurred at local to regional scales, between 0 and $30 \mathrm{~km}$ from lakeshores (Duffin et al., 2008; Higuera et al., 2011; Kelly et al., 2013; Oris et al., 2014a; Whitlock and Millspaugh, 1996). Two most recent methods developed to optimize the reconstruction of local fire events based on charcoal preserved in lake deposits are named the Charcoal Size Distribution method (hereafter CSD; Asselin and Payette, 2005b) and the Area-Count method (hereafter ARCO; Finsinger et al., 2014). However, only one study has compared the fire histories resulting from these two methods (Oris et al., 2014a). To distinguish local and regional fire events in lake charcoal deposits is not an easy task and constitutes an ongoing research challenge (Itter et al., 2017). Several procedures and numerical analyses are required to isolate fire episodes (Higuera et al., 2007) that could enclose one or more fires occurring in the charcoal source area (Gavin et al., 2007).

Thus, charcoal records from lake, peat or soil allow to reconstruct longer fire histories than tree-ring analyses. However, clear guidelines are still lacking to decide which archive and proxy to use depending on (1) temporal scale (from annual to millennial), (2) spatial scale (from local to regional), and (3) precision (from identifying historic trends to individual fire events). Only a few studies have so far compared fire histories reconstructed from various archives (e.g. tree rings, peat, soil, lake) in order to highlight similarities and differences in their outputs (Hawthorne and Mitchell, 2016; Higuera et al., 2011; Rius et al., 2011; Robin et al., 2013), but none has simultaneously addressed the three above-mentioned dimensions (temporal scale, spatial scale and precision level).

We studied two sites in the boreal forest of northeastern North America where we reconstructed fire histories using different archives and proxies to highlight their respective limits and advantages. We suggest explanations for differences between archives and proxies and we provide guidelines to choose the appropriate archive and proxy based on research objectives.

\section{Material and methods}

\subsection{Study area}

We used tree-ring analyses and charcoal records from lake sediments, peatlands and forest soils around two lakes located in the spruce-moss bioclimatic domain of Quebec (between 49 and $50^{\circ} \mathrm{N}$, and 68 and $79^{\circ} \mathrm{W}$; Fig. 1) and under a climate characterized by long cold winters and short cool summers. The two sites were selected due to their dissimilar vegetation and regional fire histories linked to regional environmental conditions. The current mean fire cycles deduced from dendrochronological investigations are around 270 years and 400 years in the regions surrounding the Innu and Lili sites, respectively (Bergeron et al., 2004; Bouchard et al., 2008). The Innu site is located in the North Shore region of eastern Quebec (Remy et al., 2017b) on glacial till and subjected to a mean annual temperature of -3 to $-1^{\circ} \mathrm{C}$ and mean annual precipitation of $1020-1110 \mathrm{~mm}$ (Leclerc et al., 2015). The Lili site is located in the Clay Belt of western Quebec (Fig. 1) and submitted to a mean annual temperature of -1 to $1{ }^{\circ} \mathrm{C}$ and mean annual precipitation of 770-940 $\mathrm{mm}$ (Leclerc et al., 2015). Both sites were also selected based on the presence of a lake with a small surface area and located close to a peatland (Table S1).

Both sites were rapidly colonized by trees after the last deglaciation, between $\mathrm{ca} .8000$ and 7000 years cal. BP (Dyke, 2004; Richard, 1995). Since then, the Lili site has been mainly dominated by Picea mariana (Mill.) B.S.P. and Pinus banksiana Lamb. (Gajewski et al., 1993; Payette, 1993; Richard, 1979), whereas the Innu site has been mainly dominated by P. mariana along with Abies balsamea (L.) Mill., and Picea glauca (Moench) Voss (King, 1986; Mott, 1976; Payette, 1993). Regional fire histories published for the two regions indicate that wildfires were more frequent between 7000 and 2000 years cal. BP than after, with a maximum frequency around 3000 years cal. BP in the northwestern region (Oris et al., 2014b) and around 5500 years cal. BP in the northeastern region (Remy et al., 2017b).

\subsection{Sampling designs}

Dendrochronology - At each site, field sampling for dendrochronological analysis was carried out in two steps. First, the largest trees (assumed to be the oldest trees) were sampled in four quadrats located in different stands less than $200 \mathrm{~m}$ from the lakeshores (Fig. S2). Second, another sampling focusing on trees with fire scars took place within $200 \mathrm{~m}$ from the lakeshores (Brossier et al., 2014). For the combined samplings, a total of 48 and 49 cross sections were sampled at the root collar at the Lili and Innu sites, respectively. Before sampling, the organic matter and mineral soil were removed from around the bases of the trees (DesRochers and Gagnon, 1997). Cross sections were dried and sanded using successively finer grades (40-600 grit) until annual growth rings and fire scars were clearly visible (Schweingruber et al., 1988). A master chronology was established with tree-ring widths of trees without fire scars (Holmes et al., 1986; Stokes and Smiley, 1968). Tree-ring analysis was performed under a binocular microscope according to standard dendrochronological methods (Niklasson et al., 2010; Stokes and Smiley, 1968). Pointer years (narrow, wide, or incomplete growth rings) were identified visually and used for crossdating (Schweingruber et al., 1990). Tree-ring widths were measured using a LINTAB 6 along two radii opposite to the fire scars and separated by $120^{\circ}$. Cross dating was achieved using the TSAPWin 4.80 software (Rinn, 2012). Scars and stand age data were analyzed using the 'dplR' package (Bunn, 2008). 

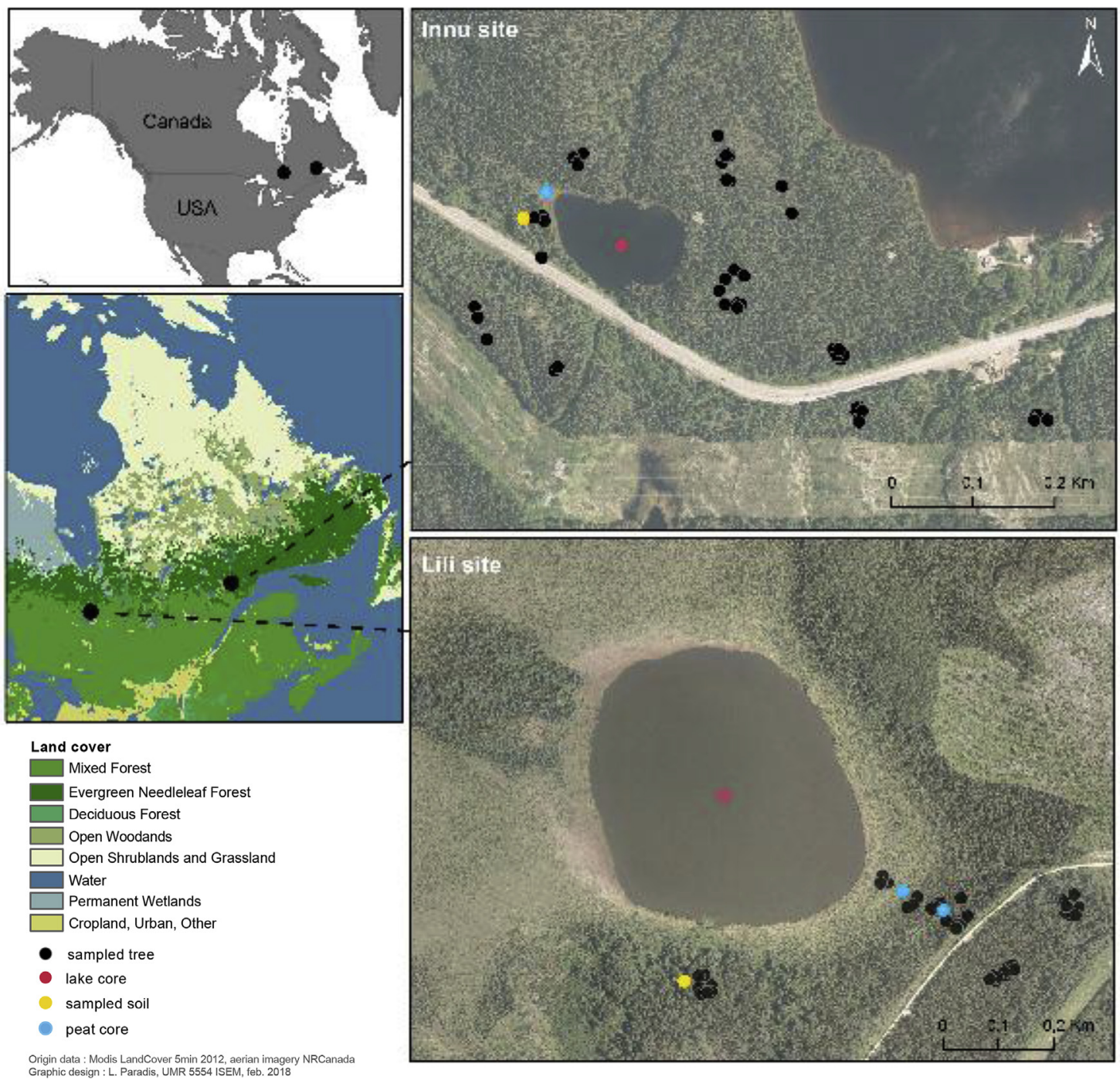

Fig. 1. Lili and Innu sites showing locations of tree, lake, soil and peat samplings.

Soil charcoal - Charcoal fragments were sampled from forest soils in $1000 \mathrm{~m}^{2}$ quadrats $(50 \times 20 \mathrm{~m})$ (Fig. 1$)$. Following a protocol modified from Payette et al. (2012) and Payette et al. (2016), we recovered soil samples along 3 transects (each $50 \mathrm{~m}$ long), separated by $10 \mathrm{~m}$. For each transect, charcoal fragments were collected every $5 \mathrm{~m}$ from samples of organic matter $(20 \times 20 \mathrm{~cm}$ quadrat $)$ and mineral soil $\left(750 \mathrm{~cm}^{3}\right.$ core extracted with a soil auger). At the Innu site, 11 samples were recovered from the first two transects and 3 samples from the third transect. At Lili site, 9 samples were recovered from each transect. Mineral soil aggregates were dispersed by immersion for $12 \mathrm{~h}$ in a sodium hydroxide solution ( $\mathrm{NaOH} 1 \%$ ) before water-sieving with a $2 \mathrm{~mm}$ mesh size. Charcoal fragments with a diameter $\geq 2 \mathrm{~mm}$ were assumed to having been produced in situ, thus representing local fires (Asselin and Payette, 2005a).

Peat charcoal - Two peat cores were extracted at the Lili site and one at the Innu site (Fig. 1) with a Russian borer. Peat cores were cut into continuous $1-\mathrm{cm}$ thick samples and charcoal fragments were extracted following a modified version of the protocol of Hörnberg et al. (1995) described in Magnan et al. (2012). Subsamples of $1 \mathrm{~cm}^{3}$ were soaked for $24 \mathrm{~h}$ in a potassium hydroxide solution ( $\mathrm{KOH} 10 \%)$ and sieved with a $0.5 \mathrm{~mm}$ mesh size. Macroscopic charcoal fragments with a long axis $>0.5 \mathrm{~mm}$, which were primarily ascribed to local or nearby fires (Hörnberg et al., 1995), were counted using a stereomicroscope at 16 to $40 \times$ magnification. In some cases, charred plant remains were identified and dated in order to reach the minimum weight required for ${ }^{14} \mathrm{C}$ dating.

Lake charcoal - Lake sediment sequences were extracted during winter from the center of each lake using a Livingstone corer (Deevey, 1965). The water-sediment interface was sampled using a Kajak-Brinkhurst gravity corer (Glew, 1988). All cores were sliced into contiguous $0.5-\mathrm{cm}$ thick samples. Sub-samples of $1 \mathrm{~cm}^{3}$ were shaken for $24 \mathrm{~h}$ in a $3 \%$ hexametaphosphate aqueous solution $\left(\mathrm{NaPO}_{3}\right)_{6}$, and then in $5 \% \mathrm{KOH}$ and $10 \% \mathrm{NaOCl}$ solutions to facilitate deflocculation as well as to differentiate black charcoal from bleached organic matter. Then, the solution was passed through a sieve to collect charcoal particles $>160 \mu \mathrm{m}$ assumed to come from fire events having occurred $0-30 \mathrm{~km}$ from the lakeshores (Higuera et al., 2011; Oris et al., 2014a). Charcoal particles were analyzed under a binocular microscope $(\times 40)$ coupled with a camera connected to a computer equipped with an image-analysis software (WinSEEDLET⿳, 2009; Regent Instruments Canada Inc.) and expressed as charcoal accumulation rates based on charcoal area or number $\left(\mathrm{mm}^{2} \mathrm{~cm}^{-1}\right.$ or $\left.\# \mathrm{~cm}^{-1}\right)$. 


\subsection{Chronological setting and fire detection}

Charcoal samples were dated using the AMS (Accelerator Mass Spectrometry) radiocarbon technique. Samples were prepared at the Center for Northern Studies (Université Laval, Québec, Canada), sent to the Keck Carbon Cycle AMS Facility (University of California, Irvine, USA) and calibrated in years before present (hereafter BP).

Soil charcoal - A total of 25 and 30 charcoal fragments from forest soils at the Lili and Innu sites, respectively, were randomly selected among those extracted. Radiocarbon dates were calibrated based on the IntCal13 data set (Reimer, 2013) with a $2 \sigma$ confidence interval using the 'clam' v2.2 package (Blaauw, 2010). Based on the sum of probabilities of all dates within each site, a unique date was attributed to each fire event with the maximum sum of probabilities within each of the age intervals corresponding to a fire event. Following de Lafontaine and de Payette, 2012 and Frégeau et al. (2015), an indirect method was used to estimate the number of fires not detected in the dated sample (Text S2; Fig. S3). To account for the inherent uncertainties of ${ }^{14} \mathrm{C}$ dating, charcoal dates with overlapping calendar years were considered to have originated from the same fire event.

Peat charcoal - A total of 13 wood charcoal or charred plant fragments ( 8 at Lili site and 5 at Innu site) were dated from distinct charred layers identified within the three peat cores (Table S2). Radiocarbon dates were calibrated based on the IntCal13 data set (Reimer, 2013) with a $2 \sigma$ confidence interval using the 'clam' v2.2 package (Blaauw, 2010). As for the soil archive, an indirect method was used to estimate the number of fires not detected in the dated sample (Text S2; Fig. S3).

Lake charcoal - Age-depth models for Innu and Lili lakes were based on eight and seven dates, respectively (Fig. S1). The 'clam' v2.2 package was used to calibrate the dates based on the IntCal13 dataset with a $2 \sigma$ confidence interval (Hua et al., 2013; Reimer, 2013). According to the chronology obtained for each lake deposit, charcoal particle abundance was expressed as accumulation (CHAR, i.e., \#.cm ${ }^{-2} \cdot \mathrm{yr}^{-1}=\mathrm{CHAR}_{\mathrm{C}}$ with charcoal particle numbers; and $\mathrm{mm}^{2} \cdot \mathrm{cm}^{-2} \cdot \mathrm{yr}^{-1}=\mathrm{CHAR}_{\mathrm{A}}$ with charcoal particle areas). CHAR series were analyzed using the CharAnalysis v1.1 software (available via https://sites.google.com/site/charanalysis/) to identify past fire events (Text S1). We also used the CSD method with a -1.77 slope value threshold to identify past local fire events characterized by charcoal particle assemblages with a higher proportion of large charcoal particles than the other assemblages resulting from regional fire events (Asselin and Payette, 2005b; Oris et al., 2014a). Finally, the ARCO method (Finsinger et al., 2014) was used with a threshold defined as the $\rho^{\text {th }}$ percentile of the distribution of bootstrapped values generated by random sampling of particle areas in each charcoal peak detected in the CHAR series. As in Oris et al. (2014a) the threshold was set at $\rho=0.90$.

\subsection{Comparison of fire reconstructions}

All fires detected from all charcoal archives are presented as 'fire periods'. Each fire period corresponds to an age range which includes one fire event recorded from a given archive and proxy, and the confidence interval around the fire date. For peat and soil, the fire period corresponds to the $2 \sigma$ confidence interval of the calibrated date (Table S2). For lake sediments, the fire period was determined from the calibrated age-depth model output (Table S3). For each site, fires from two archives or proxies were considered as similar (corresponding to the same fire) if the two recorded fire periods overlapped.

For both sites, reconstructions performed from each archive and proxy were compared in terms of percentage of similar (overlapping) and different (not overlapping) fire periods over the time covered by the shortest reconstructed history between both compared archives/proxies. The trends of reconstructed fire histories were compared using the Kolmogorov-Smirnov test on fireintervals computed as the average time between two successive fire events over the time covered by the shortest reconstructed history between both compared archives/proxies. Charcoal assemblages (in terms of number and cumulative area) recorded from lake sediment samples and corresponding to detected fire periods were compared to those not corresponding to fire periods. Comparisons were also made of charcoal assemblages (in terms of number and cumulative area) recorded from lake sediment samples and corresponding to detected fire periods from lake, soil, peat or tree-rings with those corresponding to fire periods detected only from lake sediments. Differences between these charcoal assemblages were tested for significance with Kolmogorov-Smirnov tests.

\section{Results}

\subsection{Fire reconstruction correspondences between archives}

At the Lili site, 2 fire events were detected in tree rings over a period covering the last 170 years (Fig. 2 and Fig. S2). Statistical analyses of ${ }^{14} \mathrm{C}$ dated soil charcoal allowed to detect 9 fire periods over the last 3000 years (Fig. 2 and Fig. S3; Table S2), whereas peat charcoal allowed to detect 8 fires over the last 7000 years (Fig. 2 and Fig. S3; Table S2). Analyses of lake charcoal revealed 50 fire events with $\mathrm{CHAR}_{\mathrm{C}}, 49$ with $\mathrm{CHAR}_{\mathrm{A}}, 32$ with CSD and 21 with ARCO over the last 8200 years (Fig. 2; Table S2). Between 68 and $83 \%$ of the fires periods detected in peat, soil and tree rings were also recorded in $\mathrm{CHAR}_{C}$ and $\mathrm{CHAR}_{\mathrm{A}}$, respectively (Fig. 3a), whereas $47 \%$ and $58 \%$ of the fires detected in peat, soil and tree rings corresponded to fires detected by the CSD and ARCO methods, respectively. These local fire periods corresponded to $21 \%, 27 \%, 24 \%$ and $37 \%$ of all fire periods detected by the $\mathrm{CHAR}_{\mathrm{C}}$ and $\mathrm{CHAR}_{\mathrm{A}}, \mathrm{CSD}$ and ARCO methods, respectively (Fig. $3 \mathrm{~b}$ ).

At the Innu site, 2 fire events were also detected in tree rings over a period covering the last 170 years (Fig. 2 and Fig. S2). Statistical analyses of ${ }^{14} \mathrm{C}$ dated soil charcoal allowed to detect 11 fire periods over the last 4500 years (Fig. 2 and Fig. S3; Table S2), while peat charcoal allowed to detect 5 fires over the last 3000 years (Fig. 2 and Fig. S3; Table S2). Analyses of lake charcoal revealed 75 fire events with $\mathrm{CHAR}_{\mathrm{C}}, 69$ with $\mathrm{CHAR}_{\mathrm{A}}, 32$ with CSD and 21 with ARCO over the last 8200 years (Fig. 2; Table S2). Between 83 and $89 \%$ of the fires detected in peat, soil and tree rings were also recorded in CHAR $_{C}$ and $\mathrm{CHAR}_{A}$, respectively (Fig. 3a), whereas $67 \%$ and $44 \%$ of the fires detected in peat, soil and tree rings corresponded with fires detected by the CSD and ARCO methods, respectively. These local fire periods corresponded to $25 \%, 24 \%, 40 \%$ and $27 \%$ of all fire periods detected by the $\mathrm{CHAR}_{\mathrm{C}}$ and $\mathrm{CHAR}, \mathrm{CSD}$ and ARCO methods, respectively (Fig. 3 b).

Approximately half of the fire periods detected in soil and peat were similar at Lili Lake, whereas only one fire period overlapped at Innu Lake (Fig. 2). Fire dates recorded from tree rings are included in fire periods recorded from peat and soil at Lili Lake and only from soil at Innu Lake (Fig. 2).

\subsection{Charcoal assemblages in fire reconstructions from lake sediments}

All charcoal assemblages corresponding to fire periods detected in lake sediments with the $\mathrm{CHAR}_{\mathrm{C}}$ and $\mathrm{CHAR}_{\mathrm{A}}$ methods included significantly larger and more abundant charcoal particles in average than charcoal assemblages characterizing no-fire periods (Fig. 4). In the same way, all charcoal assemblages corresponding to past local fires detected in lake sediments with the CSD and ARCO 

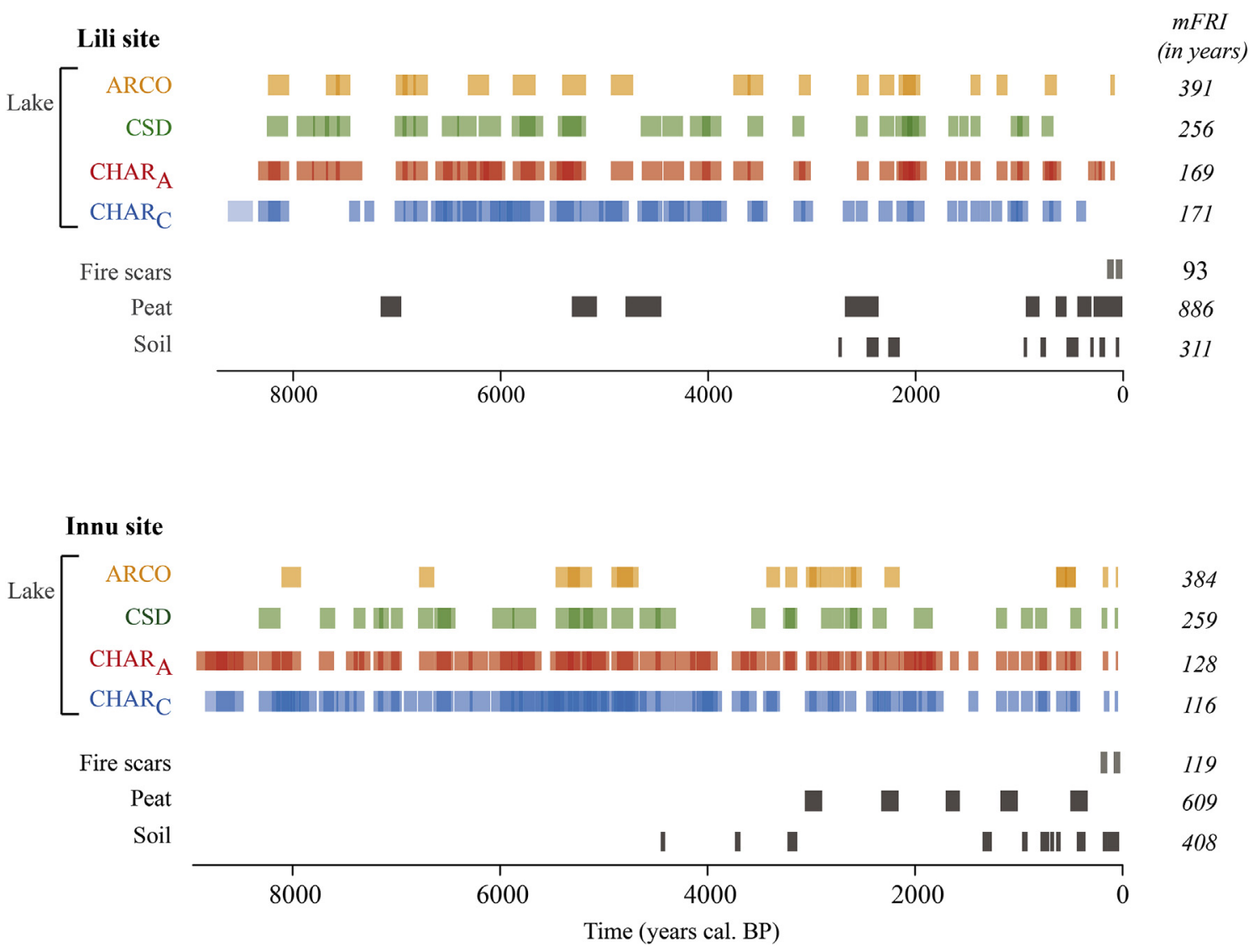

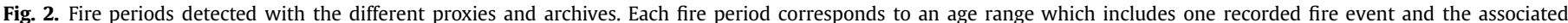

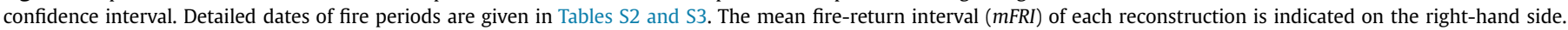

methods included significantly larger and more abundant charcoal particles in average than charcoal assemblages characterizing nofire (or regional fire) periods (Fig. 4). In contrast, charcoal assemblages corresponding to fire periods detected only from lake sediments, independently of the method used, were similar in terms of charcoal area and charcoal number to charcoal assemblages corresponding to fire periods detected in soils, peat and tree rings (Fig. 5).

\section{Discussion}

\subsection{Efficiency of fire reconstruction methods}

Even if the locations of tree-ring samples only cover a portion of each lake's watershed (especially at Lili site; Fig. S2b), dates of the fire events recorded by tree ring analyses are similar to those recorded by other studies in the same zones for both sites. Bouchard et al. (2008) recorded one fire at the Innu site around 1902 very close to the most recent fire dated by fire scar analysis around 1905 (Fig. S1); and Bergeron et al. (2004) recorded two fires close to the Lili site around 1820 and 1916 close to the fires estimated around 1830 and 1905 by stand-age (Fig. S1). Once again, tree-ring analyses are shown to be a robust proxy to reconstruct fire histories at decadal to centennial time scales (Drobyshev et al., 2017; Swetnam et al., 1999; Waito et al., 2018).

With regards to the archives used to reconstruct fire histories at multi-millennial time scales, charcoal preserved in lake sediments are known to be more influenced by long-distance dispersal than charcoal preserved in peat and soil (Higuera et al., 2007; Leys et al.,
2013; Tolonen, 1985; Whitlock and Millspaugh, 1996). This explains the high number of fires recorded with the CharAnalysis method (based on charcoal area and count), with a lot of overlap between detected fire periods and the shortest recorded fire-return intervals (Fig. 2 \& Table S5). The use of the CSD and ARCO methods allowed to remove some of the extra-local fires (Asselin and Payette, 2005b; Finsinger et al., 2014), however significantly more fires were recorded from lake sediments than from soils and peat. Nevertheless, it does not necessarily imply that fire periods detected in lakes but not in other archives all correspond to regional fires. The spatial heterogeneity of fire propagation (Madoui et al., 2010; Ouarmim et al., 2016), with zones partially or entirely escaping fire due to characteristics of the local vegetation and soil moisture (Ouarmim et al., 2014), prevent the reconstruction of all local fire events (within an entire watershed) with only one quadrat (soil) or one core (peat). Thus, some fires could have not been recorded from soil and peat due to the very localized nature of the sampling done at both sites (Fig. 1). At the Innu site, no fire was recorded in the peat before $3000 \mathrm{BP}$, maybe due to a particularly humid environment preventing the occurrence of low-severity fires. Particularly dry atmospheric conditions can also prevent some fires to be recorded in soil, peat and lake (Conedera et al., 2009; Robin et al., 2013). Indeed, high fire activity can produce ash rather than charcoal, or induce re-burning of surficial charcoal which is then transformed into ash. In addition, some fire events could have been recorded in lake sediments but not in the studied soil quadrats and/ or peat cores if they occurred, for example, on the opposite side of the watershed or if the wind was not blowing toward the studied soil quadrats or peatlands during fire (Gavin et al., 2003). Finally, 
(a)
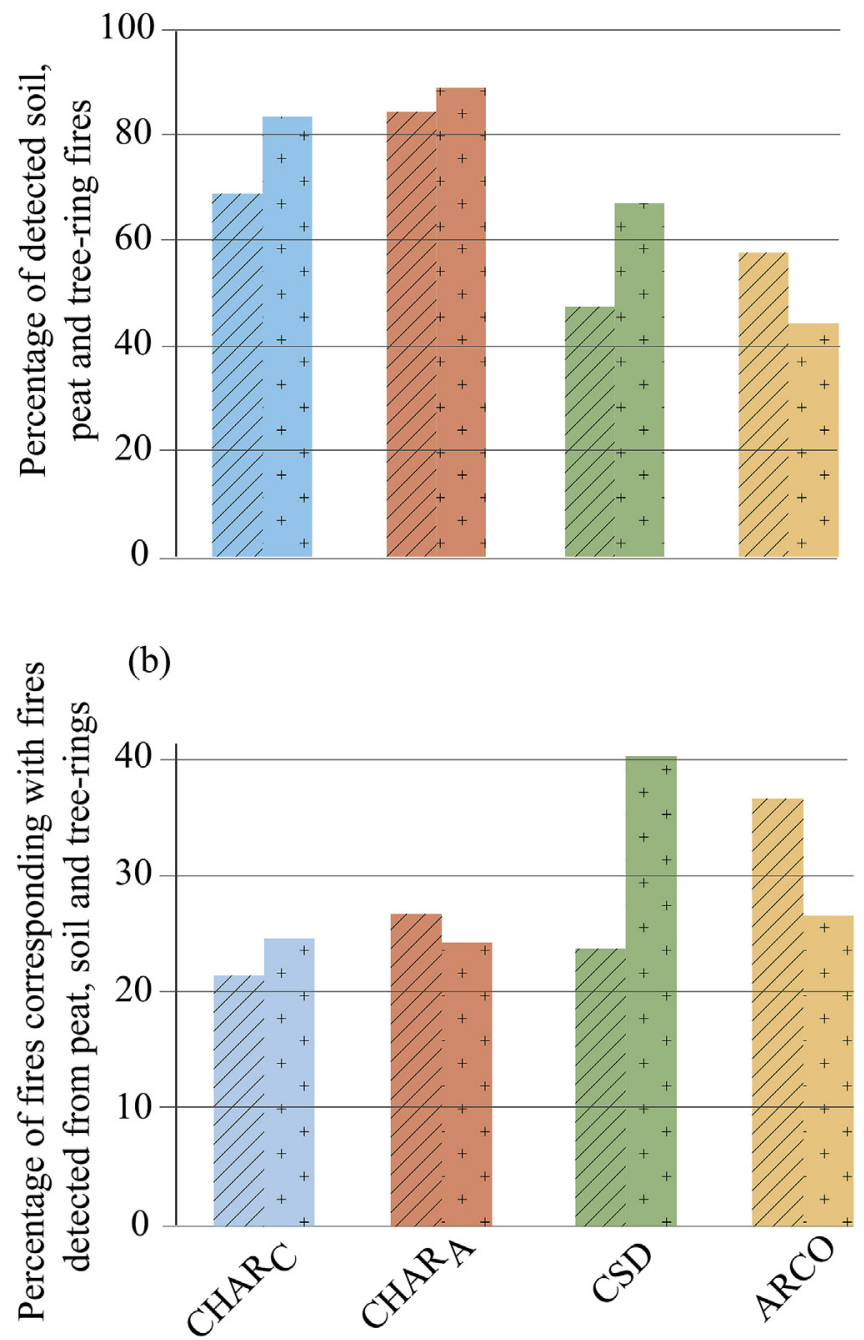

Fig. 3. Correspondence between fires detected by different archives and proxies for Lil (striped) and Innu (crosses) sites. (a) Percentages of fires detected from soil, peat and tree rings also detected with four different lake charcoal analysis methods. (b) Percentages of fires detected by lake charcoal methods corresponding to fires also detected from peat, soil and tree rings analyses.

some fire events recorded in lake sediments, peat and soil corresponding to the same fire could be recorded at different dates due to the potential influence of "inbuilt age" effect (Gavin, 2001). Some dated charcoals from soil, peat and lake (if charcoals are dated to build the age-depth model) could have been produced by dead wood present on the landscape for centuries before being burned, thus leading to incorrect radiocarbon dates.

Local fires detected from soil, peat and tree-ring analyses are sometimes recognized as more spatially and temporally precise and robust than those detected from lake sediments (Pitkänen et al., 2001). Results from the current study also showed that local fire histories reconstructed from soil and peat charcoal are similar to those reconstructed from lake charcoal with the CSD and ARCO methods (Table S4). Several soil quadrats and peat deposits located in various locations within a watershed should be sampled to more accurately reconstruct local fire histories, especially if these local histories are to be combined into regional-scale fire histories (Payette et al., 2016). Fewer ${ }^{14} \mathrm{C}$ dates could then be obtained per

\section{Charcoal} number (\#)

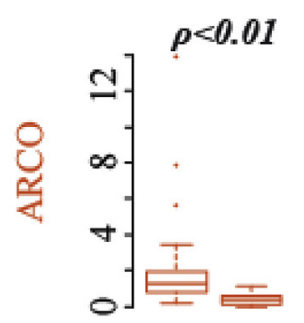

\section{Charcoal cumulative area $\left(\mathrm{mm}^{2}\right)$}
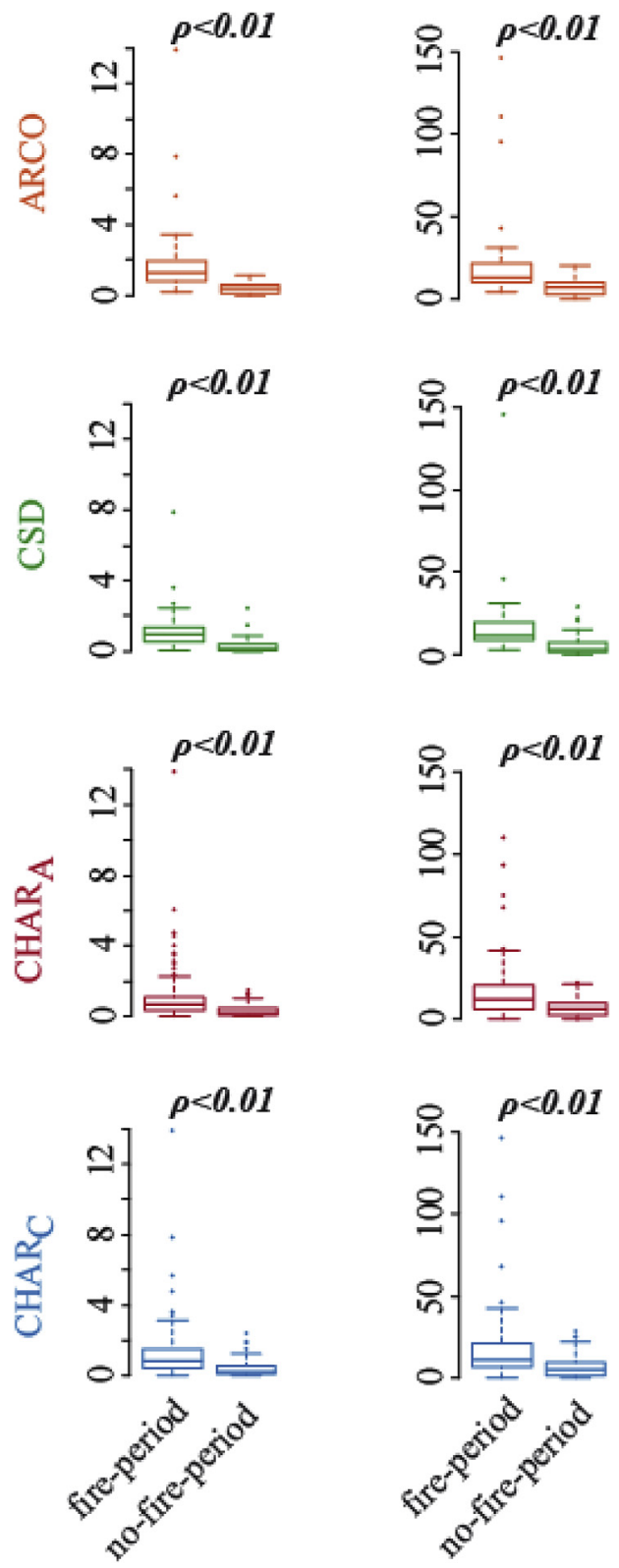

Fig. 4. Charcoal assemblages (number and area) of detected fire periods versus no-fire periods using CharAnalysis $\left(\mathrm{CHAR}_{\mathrm{C}}\right.$ in blue and $\mathrm{CHAR}_{\mathrm{A}}$ in red), CSD (green) and ARCO (yellow). The $\rho$-values were obtained from Kolmogorov-Smirnov tests. (For interpretation of the references to color in this figure legend, the reader is referred to the Web version of this article.)

quadrat/core to keep costs within reasonable limits.

Theoretical models predict that charcoal dispersal distance decreases with increasing particle size (Clark et al., 1998; Higuera et al., 2007; Patterson et al., 1987). Charcoal assemblages (count or area) of fires detected from lake sediments, including those filtered by the CSD and ARCO methods, were composed of larger and more numerous charcoal fragments than those recorded during periods with no (local) fires detected (Fig. 4). This result supports the assertion that local fire periods will result in proportionately more larger-sized charcoal fragments in lake sediment assemblages (Asselin and Payette, 2005b; Clark et al., 


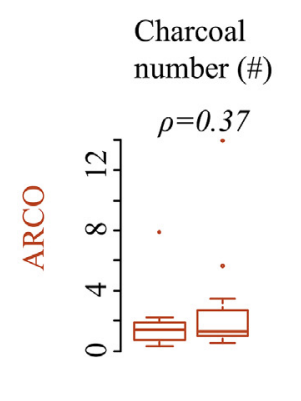

Charcoal cumulative
area $\left(\mathrm{mm}^{2}\right)$
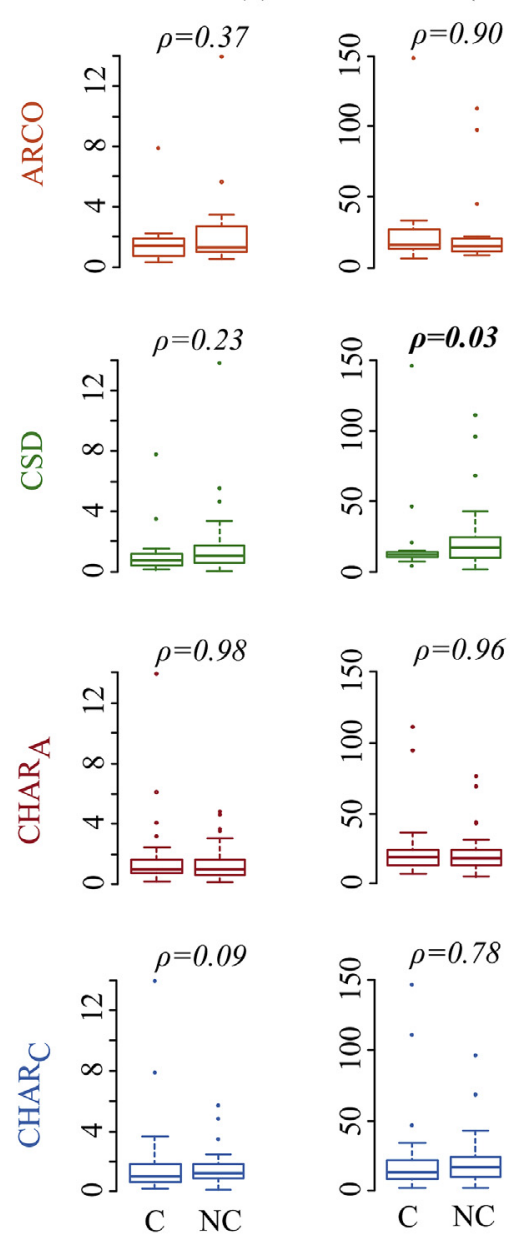

$\mathrm{C}=$ Detected fire periods corresponding to fire-periods from soil, peat and tree-ring analyses $\mathrm{NC}=$ Detected fire periods not corresponding to fire-periods from soil, peat and tree-ring analyses

Fig. 5. Charcoal assemblages (number and area) of fire periods detected in lake sediments corresponding to fire periods detected or not in soil, peat and tree ring archives. Same color legend as in Fig. 4. The $\rho$-values were obtained from Kolmogorov-Smirnov tests. (For interpretation of the references to color in this figure legend, the reader is referred to the Web version of this article.)

1998; Gardner and Whitlock, 2001; Lynch et al., 2004; Oris et al., 2014a). However, charcoal fragments deposited in lake sediments during fire periods recorded in soil and peat were neither larger nor more numerous than those deposited during periods without recorded fires in soil and peat (Fig. 5). This underlines that charcoal deposition and preservation in the three archives (peat, soil and lake) is influenced by distinct taphonomical processes. Thus, the fire signal recorded in peat and soil deposits in our study cannot be used to verify the local fire signal in lake sediments.

Approximately half of the fires detected with lake charcoal were considered local by the CSD method. This was not the case with the ARCO method, which detected around 15\% less local fire periods than the CSD method and showed millennial periods without any fire recorded. Consequently, the ARCO method led to a mean firereturn interval of almost 400 years with some periods of more than 1300 years without fire at the Innu site (Fig. 2 \& Table S5). A similar result was obtained by Oris et al. (2014a) in northwestern
Quebec. Such long periods without fire in coniferous boreal forests of Quebec are unrealistic, knowing that the study zones are recurrently affected by intense/severe and large wildfires (Remy et al., 2017a; Stocks et al., 2003). According to dendrochronological investigations, during the last 300 years, the study zones were characterized by a 100-400-year fire cycle (Bergeron et al., 2004; Bouchard et al., 2008). Hence, for boreal ecosystems, the CSD method is more efficient than the ARCO method to detect local fire periods.

That being said, approximately $50 \%$ of the fires detected in soil, peat and tree rings were not recorded by the CSD method, leading to longer fire-return intervals (Fig. 3a \& Table S5). Some of the charcoal assemblages deposited in lake sediments during fire periods recorded in soil, peat and tree rings did not contain enough charcoal, including large charcoal, to be detected in the lake record. Thus, the effect of taphonomical processes on lake charcoal could erase part of the past fire evidence by homogenizing charcoal assemblages. Hence, method applied to lake-sediment charcoal records to remove background noise resulting from taphonomic processes such as secondary deposition resulting from surface runoff, sediment mixing and redeposition (Blarquez et al., 2013; Clark and Royall, 1996; Higuera et al., 2007; Whitlock and Millspaugh, 1996) were not able to detect all the "true" past fire events. Consequently, it is conceivable that some local fire events were recorded in lake sediments, independently of the method used, but not in soil and peat, and vice versa as explained above.

Some methodological improvements could be investigated to increase the robustness of fire reconstructions. Some of the main methodological shortcomings which lead to uncertainties are the low accuracy of age-depth models, the too short verification period provided by tree-ring analyses or remote-sensing, and the relatively infrequent occurrence of large fires in these forests (Hawthorne et al., 2017; Marlon et al., 2016). Other palaeoenvironmental proxies could help identify local fires with more accuracy in the future. For example, some studies have noted correspondences between charcoal records and changes in vegetation, diatoms, geochemical composition or magnetic susceptibility (Dunnette et al., 2014; Leys et al., 2016; Ponader et al., 2002; Rummery, 1983; Senici et al., 2013; Swain, 1973).

\subsection{Which archives for which objectives?}

Due to their age, tree-ring analyses, together with written archives, satellite imagery and aerial photographs, depending on availability, remain the most accurate methods to reconstruct local fire histories in the recent past (generally $<1000$ years) (Higuera et al., 2011; Oris et al., 2014a; Swetnam et al., 1999; Waito et al., 2018). When fire dynamics must be investigated at longer, multimillennial time scales, the choice between archives and proxies depends on the study objectives and on the spatiotemporal scale considered (Fig. 6). In line with previous studies (Ali et al., 2009; Kelly et al., 2013; Lynch et al., 2004; Oris et al., 2014a), we recommend to use charcoal records from lake deposits processed with CharAnalysis (Table S4) for regional-scale fire history reconstructions. Indeed, lake-sediment charcoal analyses allow to reconstruct the longest fire histories and a large number of studies have validated their use to reconstruct long-term variations of fire regimes associated with past climate, vegetation dynamics or anthropogenic activities (Blarquez et al., 2015; Markgraf et al., 2007; Marlon et al., 2008; Millspaugh et al., 2000; Tinner et al., 2001; Waito et al., 2018). However, several lakes need to be analyzed to optimize the reconstructed regional trends in fire histories by minimizing the taphonomic biases specific to each lake (Ali et al., 2012, 2009; Blarquez et al., 2015; Calder et al., 2015; Clark and Royall, 1996; El-Guellab et al., 2015; Goring et al., 2012; Kelly 


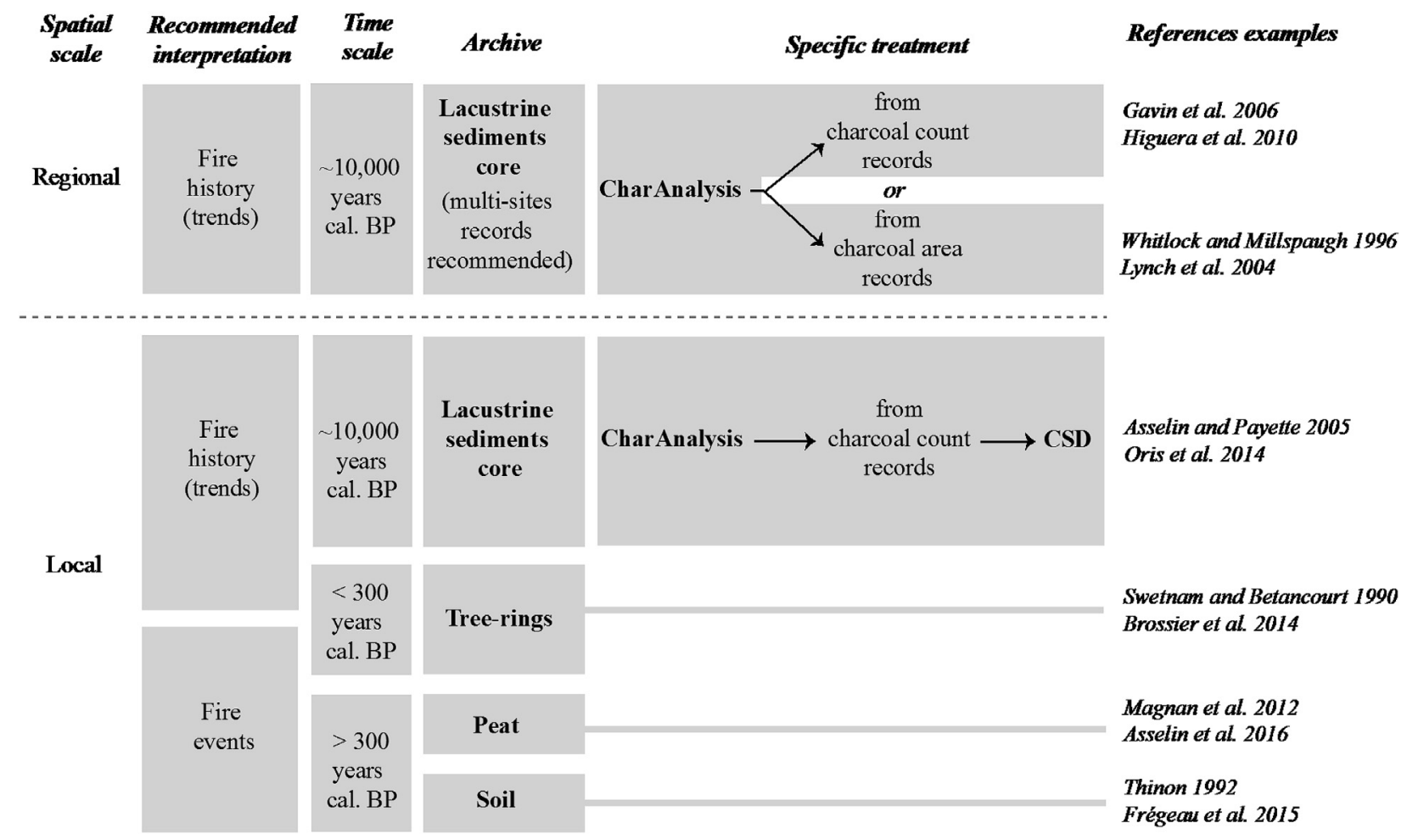

Fig. 6. Guidelines to select archive and proxy to reconstruct past fires in boreal forests.

et al., 2013; Mustaphi et al., 2015; Whitlock and Millspaugh, 1996). Fire reconstructions based on lake-sediment charcoal should be used to study low-frequency trends rather than to try and decipher individual fire events, due to the uncertainty induced by the interpolation of fire dates from imperfect age-depth models, and because one peak identified from lake-sediment charcoal series could enclose one or more fires (Gavin et al., 2006; Higuera et al., 2010). Additionally, as the topmost (i.e. the most recent) lake sediments often have low density, less charcoal fragments are generally recovered from the corresponding samples, possibly leading to underestimating the number of detected fires (Lehman, 1975). Charcoal from soil and peat can also be used to reconstruct regional scale fire histories more robustly if several sites are studied (Frégeau et al., 2015; Couillard et al., 2016). However, regional reconstructions based on soil or peat charcoal will be much more expensive (requiring much more radiocarbon dates), and more time-consuming, both in the field and in the lab.

When aiming to reconstruct local fires, different options are available, depending on the study objectives (Fig. 6). Charcoal embedded in peat and soil can more accurately date fire events than charcoal in lake sediments because of the error attributable to age interpolation of lake sediments whereas charcoals are dated directly in peat and soil (Asselin and Payette, 2005b; Finsinger et al., 2014; Robin et al., 2013). Nevertheless, fire events detected from peat and soil should be inferred from a sufficient number of dated charcoal particles of from short-lived species to minimize the potential influence of the "inbuilt age" effect (Frégeau et al., 2015; Gavin, 2001; Magnan et al., 2012). Thus, peat and soil are more adapted archives than lake sediments to study the environmental processes related to past individual local fires older than the period covered by tree-ring analyses, such as watershed erosion, biogeochemical cycles and local vegetation dynamics (Garneau et al., 2018; Payette and Delwaide, 2004; Poirier et al., 2014). However, charcoal from lake sediments are better suited to reconstruct longterm fire dynamics in boreal forests, as they give the longest fire histories and are not subject to loss to re-burning or to variations in sediment accumulation. Hence, fire histories reconstructed from the CSD method are more appropriate for studying trends at the local scale because they remove a large part of the regional fires (Fig. 6).

To conclude, the choice of which archive and proxy to use to reconstruct past fire histories depends mainly on the study objectives, particularly on the spatiotemporal scale considered. At the regional scale, charcoal records from lake sediments treated with CharAnalysis are currently the most appropriate to reconstruct low-frequency trends, but require the analysis of several lakes. At the local scale, more than one archive is suitable for fire history reconstruction. Charcoal records from lake sediments treated with CharAnalysis and then filtered with the CSD method allow to reconstruct the longest local fire histories, but again, focusing on trends rather than on the identification of individual fire events. Charcoal records from peat and soils are the best choice if the study objectives request accurate fire dates. Finally, tree-rings analyses remain the most efficient method to study fire histories at decadal to centennial-time scales.

\section{Acknowledgments}

This research was funded by the Natural Sciences and Engineering Research Council of Canada (NSERC-STPGP 479283-15), the Fonds de Recherche du Québec - Nature et Technologies (FRQNT2014-PR-173570), the Centre National de la Recherche Scientifique (CNRS France), the MITACS program (MITACS-IT08209, MITACSIT04396 and MITACS-IT03922) in association with the Ministère des Forêts, de la Faune et des Parcs du Québec, Barrette-Chapais Ltd and the Institut Écologie et Environnement through the GDRI "Forêts Froides". We thank D. Gervais and S. Paradis for their participation in fieldwork, M. Casu and E. Le Stum-Boivin for their participation in fieldwork and their work on dendrochronological analyses and peat analyses, respectively, Y. Dubord and J. Lemieux 
for their work on dendrochronological analyses, R. Robles and L. Veilleux for their work on charcoal analyses, S. Canal for her help with charcoal data acquisition, V. Poirier and L. Paradis for their work with GIS data and their help with map editing, P. Clouâtre for fieldwork monitoring and R. Julien and D. Charron for their help with project logistics.

\section{Appendix A. Supplementary data}

Supplementary data related to this article can be found at https://doi.org/10.1016/j.quascirev.2018.06.010.

\section{References}

Agee, J., 1998. The landscape ecology of western forest fire regimes. Northwest Sci. $72,24-34$.

Agee, J.K., 1993. Fire Ecology of Pacific Northwest Forests. Island Press, Washington, DC.

Ali, A.A., Blarquez, O., Girardin, M.P., Hély, C., Tinquaut, F., Guellab, A.E., Valsecchi, V., Terrier, A., Bremond, L., Genries, A., Gauthier, S., Bergeron, Y., 2012. Control of the multimillennial wildfire size in boreal North America by spring climatic conditions. Proc. Natl. Acad. Sci. Unit. States Am. 109, 20966-20970. https://doi. org/10.1073/pnas.1203467109.

Ali, A.A., Carcaillet, C., Bergeron, Y., 2009. Long-term fire frequency variability in the eastern Canadian boreal forest: the influences of climate vs. local factors. Global Change Biol. 15, 1230-1241. https://doi.org/10.1111/j.1365-2486.2009.01842.x.

Asselin, H., Payette, S., 2005a. Late Holocene deforestation of a tree line site: estimation of pre-fire vegetation composition and black spruce cover using soil charcoal. Ecography 28, 801-805. https://doi.org/10.1111/j.2005.0906-7590. 04216.x.

Asselin, H., Payette, S., 2005b. Detecting local-scale fire episodes on pollen slides. Rev. Palaeobot. Palynol. 137, 31-40. https://doi.org/10.1016/j.revpalbo.2005.08. 002.

Bergeron, Y., Gauthier, S., Flannigan, M., Kafka, V., 2004. Fire regimes at the transition between mixedwood and coniferous boreal forest in northwestern quebec. Ecology 85, 1916-1932. https://doi.org/10.1890/02-0716.

Blaauw, M., 2010. Methods and code for 'classical' age-modelling of radiocarbon sequences. Quat. Geochronol. 5, 512-518. https://doi.org/10.1016/j.quageo.2010. 01.002.

Blarquez, O., Ali, A.A., Girardin, M.P., Grondin, P., Fréchette, B., Bergeron, Y., Hély, C., 2015. Regional paleofire regimes affected by non-uniform climate, vegetation and human drivers. Sci. Rep. 5. https://doi.org/10.1038/srep13356.

Blarquez, O., Girardin, M.P., Leys, B., Ali, A.A., Aleman, J.C., Bergeron, Y., Carcaillet, C. 2013. Paleofire reconstruction based on an ensemble-member strategy applied to sedimentary charcoal. Geophys. Res. Lett. 40, 2667-2672. https://doi.org/10. $1002 / g r l .50504$.

Bond, W.J., Woodward, F.I., Midgley, G.F., 2005. The global distribution of ecosystems in a world without fire. New Phytol. 165, 525-538. https://doi.org/10.1111/ j.1469-8137.2004.01252.x.

Bouchard, M., Pothier, D., Gauthier, S., 2008. Fire return intervals and tree species succession in the North Shore region of eastern Quebec. Can. J. For. Res. 38, 1621-1633. https://doi.org/10.1139/X07-201.

Brossier, B., Oris, F., Finsinger, W., Asselin, H., Bergeron, Y., Ali, A.A., 2014. Using treering records to calibrate peak detection in fire reconstructions based on sedimentary charcoal records. Holocene 24, 635-645. https://doi.org/10.1177/ 0959683614526902.

Bunn, A.G., 2008. A dendrochronology program library in $R$ (dplR). Dendrochronologia 26, 115-124. https://doi.org/10.1016/j.dendro.2008.01.002.

Calder, W.J., Parker, D., Stopka, C.J., Jiménez-Moreno, G., Shuman, B.N., 2015. Medieval warming initiated exceptionally large wildfire outbreaks in the. Rocky Mountains. Proc. Natl. Acad. Sci. 112, 13261-13266. https://doi.org/10.1073/ pnas.1500796112.

Carcaillet, C., Bouvier, M., Fréchette, B., Larouche, A.C., Richard, P.J.H., 2001. Comparison of pollen-slide and sieving methods in lacustrine charcoal analyses for local and regional fire history. Holocene 11, 467-476. https://doi.org/10.1191/ 095968301678302904.

Clark, J.S., Lynch, J., Stocks, B.J., Goldammer, J.G., 1998. Relationships between charcoal particles in air and sediments in west-central Siberia. Holocene 8, 19-29. https://doi.org/10.1191/095968398672501165.

Clark, J.S., Royall, P.D., 1996. Local and regional sediment charcoal evidence for fire regimes in presettlement north-eastern North America. J. Ecol. 84, 365-382. https://doi.org/10.2307/2261199.

Conedera, M., Tinner, W., Neff, C., Meurer, M., Dickens, A.F., Krebs, P., 2009 Reconstructing past fire regimes: methods, applications, and relevance to fire management and conservation. Quat. Sci. Rev. 28, 555-576. https://doi.org/10. 1016/j.quascirev.2008.11.005.

Couillard, P.-L., Frégeau, M., Payette, S., Grondin, P., Lavoie, M., 2016. Dynamique et variabilité naturelle de la pessière à mousses au nord de la région du Lac-SaintJean. Ministère de la Forêt. de la Faune et des Parcs, Québec, QC.

de Lafontaine, G., de Payette, S., 2012. Long-term fire and forest history of subalpine balsam fir (Abies balsamea) and white spruce (Picea glauca) stands in eastern Canada inferred from soil charcoal analysis. Holocene 22, 191-201. https://doi. org/10.1177/0959683611414931.

DesRochers, A., Gagnon, R., 1997. Is ring count at ground level a good estimation of black spruce age? Can. J. For. Res. 27, 1263-1267. https://doi.org/10.1139/x97086.

Deevey, E., 1965. Sampling lake sediments by use of the Livingstone sampler. In Kummel, B., Raup, D. (Eds.), Handbook of Paleontological Techniques. Freeman, San Francisco, pp. 521-529.

Dieterich, J.H., Swetnam, T.W., 1984. Notes: dendrochronology of a fire-scarred ponderosa pine. For. Sci. 30, 238-247.

Drobyshev, I., Bergeron, Y., Girardin, M.P., Gauthier, S., Ols, C., Ojal, J., 2017. Strong gradients in forest sensitivity to climate change revealed by dynamics of forest fire cycles in the Post Little Ice Age Era. J. Geophys. Res. Biogeosciences 122, 2017JG003826. https://doi.org/10.1002/2017JG003826.

Duffin, K.I., Gillson, L., Willis, K.J., 2008. Testing the sensitivity of charcoal as an indicator of fire events in savanna environments: quantitative predictions of fire proximity, area and intensity. Holocene 18, 279-291. https://doi.org/10. 1177/0959683607086766.

Dunnette, P.V., Higuera, P.E., McLauchlan, K.K., Derr, K.M., Briles, C.E., Keefe, M.H. 2014. Biogeochemical impacts of wildfires over four millennia in a Rocky Mountain subalpine watershed. New Phytol. 203, 900-912. https://doi.org/10. $1111 /$ nph.12828.

Dyke, A., 2004. An Outline of North American Deglaciation with Emphasis on central and Northern Canada, in: Quaternary Glaciations - Extent and Chronology: Part II: North America. Elsevier, Amsterdam, The Netherlands, pp. 373-424.

El-Guellab, A., Asselin, H., Gauthier, S., Bergeron, Y., Ali, A.A., 2015. Holocene variations of wildfire occurrence as a guide for sustainable management of the northeastern Canadian boreal forest. For. Ecosyst 2, 1-7. https://doi.org/10.1186/ s40663-015-0039-2.

Falk, D.A., Heyerdahl, E.K., Brown, P.M., Farris, C., Fulé, F.P., McKenzie, D., Swetnam, T.W., Taylor, A.H., Van Horne, M.L., 2011. Multi-scale controls of historical forest-fire regimes: new insights from fire-scar networks. Front. Ecol. Environ. 9, 446-454. https://doi.org/10.1890/100052.

Finsinger, W., Kelly, R., Fevre, J., Magyari, E.K., 2014. A guide to screening charcoa peaks in macrocharcoal-area records for fire-episode reconstructions. Holocene 24, 1002-1008. https://doi.org/10.1177/0959683614534737.

Frégeau, M., Payette, S., Grondin, P., 2015. Fire history of the central boreal forest in eastern North America reveals stability since the mid-Holocene. Holocene 25 1912-1922. https://doi.org/10.1177/0959683615591361.

Gajewski, K., Payette, S., Ritchie, J.C., 1993. Holocene vegetation history at the boreal-forest-shrub-tundra transition in north-western Quebec. J. Ecol. 81, 433-443. https://doi.org/10.2307/2261522.

Gardner, J.J., Whitlock, C., 2001. Charcoal accumulation following a recent fire in the Cascade Range, northwestern USA, and its relevance for fire-history studies. Holocene 11, 541-549. https://doi.org/10.1191/095968301680223495.

Garneau, M., Tremblay, L., Magnan, G., 2018. Holocene Pool Formation in Oligotrophic Fens from Boreal Quebec in Northeastern Canada. The Holocene, 0959683617729439. https://doi.org/10.1177/0959683617729439.

Gavin, D.G., 2001. Estimation of inbuilt age in radiocarbon ages of soil charcoal for fire history studies. Radiocarbon 43, 27-44. https://doi.org/10.1017/ S003382220003160X

Gavin, D.G., Brubaker, L.B., Lertzman, K.P., 2003. An 1800-year record of the spatial and temporal distribution of fire from the west coast of Vancouver Island, Canada. Can. J. For. Res. 33, 573-586. https://doi.org/10.1139/x02-196.

Gavin, D.G., Hallett, D.J., Hu, F.S., Lertzman, K.P., Prichard, S.J., Brown, K.J., Lynch, J.A., Bartlein, P., Peterson, D.L., 2007. Forest fire and climate change in western North America: insights from sediment charcoal records. Front. Ecol. Environ. 5, 499-506. https://doi.org/10.1890/060161.

Gavin, D.G., Hu, F.S., Lertzman, K., Corbett, P., 2006. Weak climatic control of standscale fire history during the late holocene. Ecology 87, 1722-1732. https:// doi.org/10.1890/0012-9658(2006)87[1722:WCCOSF]2.0.CO;2.

Glew, J.R., 1988. A portable extruding device for close interval sectioning of unconsolidated core samples. J. Paleolimnol. 1, 235-239.

Goring, S., Williams, J.W., Blois, J.L., Jackson, S.T., Paciorek, C.J., Booth, R.K., Marlon, J.R., Blaauw, M., Christen, J.A., 2012. Deposition times in the northeastern United States during the Holocene: establishing valid priors for Bayesian age models. Quat. Sci. Rev. 48, 54-60. https://doi.org/10.1016/j. quascirev.2012.05.019.

Granström, A., 2001. Fire management for biodiversity in the european boreal forest. Scand. J. For. Res. 16, 62-69. https://doi.org/10.1080/ 028275801300090627.

Hawthorne, D., Courtney Mustaphi, C.J., Aleman, J.C., Blarquez, O., Colombaroli, D. Daniau, A.-L., Marlon, J.R., Power, M., Vannière, B., Han, Y., Hantson, S. Kehrwald, N., Magi, B., Yue, X., Carcaillet, C., Marchant, R., Ogunkoya, A Githumbi, E.N., Muriuki, R.M., 2017. Global Modern Charcoal Dataset (GMCD): a tool for exploring proxy-fire linkages and spatial patterns of biomass burning. Quat. Int. https://doi.org/10.1016/j.quaint.2017.03.046.

Hawthorne, D., Mitchell, F.J.G., 2016. Identifying past fire regimes throughout the Holocene in Ireland using new and established methods of charcoal analysis. Quat. Sci. Rev. 137, 45-53. https://doi.org/10.1016/j.quascirev.2016.01.027.

Higuera, P.E., Gavin, D.G., Bartlein, P.J., Hallett, D.J., 2010. Peak detection in sediment-charcoal records: impacts of alternative data analysis methods on fire-history interpretations. Int. J. Wildland Fire 19, 996-1014. https://doi.org 
10.1071/WF09134.

Higuera, P.E., Peters, M.E., Brubaker, L.B., Gavin, D.G., 2007. Understanding the origin and analysis of sediment-charcoal records with a simulation model. Quat. Sci. Rev. 26, 1790-1809. https://doi.org/10.1016/j.quascirev.2007.03.010.

Higuera, P.E., Whitlock, C., Gage, J.A., 2011. Linking tree-ring and sediment-charcoal records to reconstruct fire occurrence and area burned in subalpine forests of Yellowstone National Park, USA. Holocene 21, 327-341. https://doi.org/10.1177/ 0959683610374882.

Holmes, R.L., Adams, R.K. Fritts, H.C. 1986. Tree-ring Chronologies of Western North America: California, Eastern Oregon and Northern Great Basin with Procedures Used in the Chronology Development Work Including Users Manuals for Computer Programs COFECHA and ARSTAN (Natural History Report No. 85721), Chronology Series VI. Laboratory of Tree-ring Research. University of Arizona, Tucson, AZ

Hörnberg, G., Ohlson, M., Zackrisson, O., 1995. Stand dynamics, regeneration patterns and long-term continuity in boreal old-growth Picea abies swamp-forests. J. Veg. Sci. 6, 291-298. https://doi.org/10.2307/3236224.

Hua, Q., Barbetti, M., Rakowski, A.Z., 2013. Atmospheric radiocarbon for the period 1950-2010. Radiocarbon 55, 2059-2072. https://doi.org/10.2458/azu_js_rc v55i2.16177.

Itter, M.S., Finley, A.O., Hooten, M.B., Higuera, P.E., Marlon, J.R., Kelly, R., McLachlan, J.S., 2017. A model-based approach to wildland fire reconstruction using sediment charcoal records. Environmetrics 28. https://doi.org/10.1002/ env. 2450

Kelly, R., Chipman, M.L., Higuera, P.E., Stefanova, I., Brubaker, L.B., Hu, F.S., 2013 Recent burning of boreal forests exceeds fire regime limits of the past 10,000 years. Proc. Natl. Acad. Sci. Unit. States Am. 110, 13055-13060. https://doi.org 10.1073/pnas.1305069110.

Kelly, R., Genet, H., McGuire, A.D., Hu, F.S., 2016. Palaeodata-informed modelling of large carbon losses from recent burning of boreal forests. Nat. Clim. Change 6 79-82. https://doi.org/10.1038/nclimate2832.

King, G.A., 1986. Deglaciation and Vegetation History of Western Labrador and Adjacent Quebec (Thesis). University of Minnesota, USA.

Leclerc, L., Siron, R., Logan, T., Côté, H., 2015. Towards Adaptation: Synthesis on Climate Change Knowledge in Québec. Ouranos, Montréal, Canada.

Lehman, J.T., 1975. Reconstructing the rate of accumulation of lake sediments: the effect of sediment focusing. Quat. Res. (Duluth) 5, 541-550. https://doi.org/10. 1016/0033-5894(75)90015-0.

Lertzman, K., Gavin, D., Hallett, D., Brubaker, L., Lepofsky, D., Mathewes, R., 2002. Long-term fire regime estimated from soil charcoal in coastal temperate rainforests. Conserv. Ecol. 6 (5). http://hdl.handle.net/10535/2577.

Leys, B., Carcaillet, C., Dezileau, L., Ali, A.A., Bradshaw, R.H.W., 2013. A comparison of charcoal measurements for reconstruction of Mediterranean paleo-fire frequency in the mountains of Corsica. Quat. Res. (Duluth) 79, 337-349. https:/ doi.org/10.1016/j.yqres.2013.01.003.

Leys, B., Higuera, P.E., McLauchlan, K.K., Dunnette, P.V., 2016. Wildfires and geochemical change in a subalpine forest over the past six millennia. Environ. Res. Lett. 11 (125003). https://doi.org/10.1088/1748-9326/11/12/125003.

Lynch, J.A., Hollis, J.L., Hu, F.S., 2004. Climatic and landscape controls of the boreal forest fire regime: holocene records from Alaska. J. Ecol. 92, 477-489. https:/ doi.org/10.1111/j.0022-0477.2004.00879.X.

Madoui, A., Leduc, A., Gauthier, S., Bergeron, Y., 2010. Spatial pattern analyses of post-fire residual stands in the black spruce boreal forest of western Quebec. Int. J. Wildland Fire 19, 1110-1126. https://doi.org/10.1071/WF10049.

Magnan, G., Lavoie, M., Payette, S., 2012. Impact of fire on long-term vegetation dynamics of ombrotrophic peatlands in northwestern Quebec, Canada. Quat. Res. (Duluth) 77, 110-121. https://doi.org/10.1016/j.yqres.2011.10.006.

Markgraf, V., Whitlock, C., Haberle, S., 2007. Vegetation and fire history during the last 18,000 cal yr B.P. In southern patagonia: Mallín pollux, coyhaique, province aisén ( $45^{\circ} 41^{\prime} 30^{\prime \prime} \mathrm{S}, 71^{\circ} 50^{\prime} 30^{\prime \prime} \mathrm{W}, 640 \mathrm{~m}$ elevation). Palaeogeogr. Palaeoclimatol. Palaeoecol. 254, 492-507. https://doi.org/10.1016/j.palaeo.2007.07.008.

Marlon, J.R., Bartlein, P.J., Carcaillet, C., Gavin, D.G., Harrison, S.P., Higuera, P.E., Joos, F., Power, M.J., Prentice, I.C., 2008. Climate and human influences on global biomass burning over the past two millennia. Nat. Geosci. 1, 697-702. https:/ doi.org/10.1038/ngeo313.

Marlon, J.R., Kelly, R., Daniau, A.-L., Vannière, B., Power, M.J., Bartlein, P., Higuera, P., Blarquez, O., Brewer, S., Brücher, T., Feurdean, A., Romera, G.G., Iglesias, V., Maezumi, S.Y., Magi, B., Courtney Mustaphi, C.J., Zhihai, T., 2016. Reconstructions of biomass burning from sediment-charcoal records to improve data-model comparisons. Biogeosciences 13, 3225-3244. https://doi.org/10. 5194/bg-13-3225-2016.

Millspaugh, S.H., Whitlock, C., Bartlein, P.J., 2000. Variations in fire frequency and climate over the past $17000 \mathrm{yr}$ in central Yellowstone National Park. Geology 28, 211-214. https://doi.org/10.1130/0091-7613(2000)28<211:VIFFAC>2.0.CO;

Mott, R.J., 1976. Holocene pollen profile from the sept iles area, quebec. Nat. Can. (Que.) 103, 457-467.

Mustaphi, C.J.C., Davis, E.L., Perreault, J.T., Pisaric, M.F.J., 2015. Spatial variability of recent macroscopic charcoal deposition in a small montane lake and implications for reconstruction of watershed-scale fire regimes. J. Paleolimnol. 54 71-86. https://doi.org/10.1007/s10933-015-9838-2.

Niklasson, M., Zin, E., Zielonka, T., Feijen, M., Korczyk, A.F., Churski, M., Samojlik, T., Jedrzejewska, B., Gutowski, J.M., Brzeziecki, B., 2010. A 350-year tree-ring fire record from Białowieża Primeval Forest, Poland: implications for Central European lowland fire history. J. Ecol. 98, 1319-1329. https://doi.org/10.1111/. 1365-2745.2010.01710.x

Ohlson, M., Tryterud, E., 2000. Interpretation of the charcoal record in forest soils: forest fires and their production and deposition of macroscopic charcoal. Holocene 10, 519-525. https://doi.org/10.1191/095968300667442551.

Oris, F., Ali, A.A., Asselin, H., Paradis, L., Bergeron, Y., Finsinger, W., 2014a. Charcoal dispersion and deposition in boreal lakes from 3 years of monitoring: differences between local and regional fires. Geophys. Res. Lett. 41, 2014GL060984. https://doi.org/10.1002/2014GL060984.

Oris, F., Asselin, H., Finsinger, W., Hély, C., Blarquez, O., Ferland, M.-E., Bergeron, Y. Ali, A.A., 2014b. Long-term fire history in northern Quebec: implications for the northern limit of commercial forests. J. Appl. Ecol. 51, 675-683. https://doi.org/ 10.1111/1365-2664.12240.

Ouarmim, S., Ali, A.A., Asselin, H., Hély, C., Bergeron, Y., 2015. Evaluating the persistence of post-fire residual patches in the eastern Canadian boreal mixedwood forest. Boreas 44, 230-239. https://doi.org/10.1111/bor.12087.

Ouarmim, S., Asselin, H., Bergeron, Y., Ali, A.A., Hély, C., 2014. Stand structure in fire refuges of the eastern Canadian boreal mixedwood forest. For. Ecol. Manag 324 1-7. https://doi.org/10.1016/j.foreco.2014.03.034

Ouarmim, S., Paradis, L., Asselin, H., Bergeron, Y., Ali, A.A., Hély, C., 2016. Burning potential of fire refuges in the boreal mixedwood forest. Forests 7 (246). https: / doi.org/10.3390/f7100246.

Patterson, W.A., Edwards, K.J., Maguire, D.J., 1987. Microscopic charcoal as a fossil indicator of fire. Quat. Sci. Rev. 6, 3-23. https://doi.org/10.1016/0277-3791(87) 90012-6.

Payette, S., 1993. The range limit of boreal tree species in Quebec-Labrador: an ecological and palaeoecological interpretation. Rev. Palaeobot. Palynol. 79, 7-30. https://doi.org/10.1016/0034-6667(93)90036-T.

Payette, S., Delwaide, A., 2004. Dynamics of subarctic wetland forests over the past 1500 years. Ecol. Monogr. 74, 373-391. https://doi.org/10.1890/03-4033.

Payette, S., Delwaide, A., Schaffhauser, A., Magnan, G., 2012. Calculating long-term fire frequency at the stand scale from charcoal data. Ecosphere 3, 1-16. https://doi.org/10.1890/ES12-00026.1.

Payette, S., Pilon, V., Couillard, P.-L., Frégeau, M., 2016. Long-term fire history of maple (Acer) forest sites in the central St. Lawrence Lowland. Quebec. Can. J. For. Res. 46, 822-831. https://doi.org/10.1139/cjfr-2015-0305.

Pitkänen, A., Tolonen, K., Jungner, H., 2001. A basin-based approach to the longterm history of forest fires as determined from peat strata. Holocene 11, 599-605. https://doi.org/10.1191/095968301680223558.

Poirier, V., Paré, D., Boiffin, J., Munson, A.D., 2014. Combined influence of fire and salvage logging on carbon and nitrogen storage in boreal forest soil profiles. For. Ecol. Manag 326, 133-141. https://doi.org/10.1016/j.foreco.2014.04.021.

Ponader, K., Pienitz, R., Vincent, W., Gajewski, K., 2002. Limnological conditions in a subarctic lake (northern Québec, Canada) during the late Holocene: analyses based on fossil diatoms. J. Paleolimnol. 27, 353-366. https://doi.org/10.1023/A: 1016033028144

Reimer, P., 2013. IntCal13 and Marine13 radiocarbon age calibration curves 0-50,000 years cal BP. Radiocarbon 55, 1869-1887. https://doi.org/10.2458/ azu_js_rc.55.16947.

Remy, C.C., Hély, C., Blarquez, O., Magnan, G., Bergeron, Y., Lavoie, M., Ali, A.A., 2017a. Different regional climatic drivers of Holocene large wildfires in boreal forests of northeastern America. Environ. Res. Lett. 12, 035005. https://doi.org/ 10.1088/1748-9326/aa5aff.

Remy, C.C., Lavoie, M., Girardin, M.P., Hély, C., Bergeron, Y., Grondin, P., Oris, F., Asselin, H., Ali, A.A., 2017b. Wildfire size alters long-term vegetation trajectories in boreal forests of eastern North America. J. Biogeogr. 44, 1268-1279. https:// doi.org/10.1111/jbi.12921.

Richard, P., 1979. Contribution à l'histoire postglaciaire de la végétation au nord-est de la Jamésie, Nouveau-Québec. Géogr. Phys. Quaternaire 33, 93-112. https:// doi.org/10.7202/1000324ar.

Richard, P.J.H., 1995. Le couvert végétal du Québec-Labrador il y a 6000 ans BP: essai. Géogr. Phys. Quaternaire 49 (117). https://doi.org/10.7202/033033ar.

Rinn, F., 2012. Tsap-win: Time Series Analysis and Presentation for Dendrochronology and Related Applications (No. Version 4.80 User Reference). RINNTECH, Heidelberg.

Rius, D., Vannière, B., Galop, D., Richard, H., 2011. Holocene fire regime changes from multiple-site sedimentary charcoal analyses in the Lourdes basin (Pyrenees, France). Quat. Sci. Rev. 30, 1696-1709. https://doi.org/10.1016/j.quascirev.2011. 03.014.

Robin, V., Knapp, H., Rickert, B.-H., Talon, B., Nelle, O., 2013. Comparison of holocene anthracological signals, from various types of archives in Germany: toward a more detailed reconstruction of fire history? Quat. Rev. Assoc. Fr. Pour Létude Quat 167-177. https://doi.org/10.4000/quaternaire.6566.

Rummery, T.A., 1983. The use of magnetic measurements in interpreting the fire histories of lake drainage basins. Hydrobiologia 103, 53-58. https://doi.org/10. 1007/BF00028427.

Sanborn, P., Geertsema, M., Jull, A.J.T., Hawkes, B., 2006. Soil and sedimentary charcoal evidence for Holocene forest fires in an inland temperate rainforest, east-central British Columbia, Canada. Holocene 16, 415-427. https://doi.org/ 10.1191/0959683606hl937rp.

Schweingruber, F.H., Bartholin, T., Schaur, E., Briffa, K.R., 1988. Radiodensitometricdendroclimatological conifer chronologies from lapland (scandinavia) and the alps (Switzerland). Boreas 17, 559-566. https://doi.org/10.1111/j.1502-3885. 1988.tb00569.x.

Schweingruber, F.H., Eckstein, D., Serre-Bachet, F., Bräker, O.U., 1990. Identification, presentation and interpretation of event years and pointer years in 
dendrochronology. Dendrochronologia 8, 9-38. https://www.dora.lib4ri.ch/ wsl/islandora/object/wsl:2189.

Senici, D., Lucas, A., Chen, H.Y.H., Bergeron, Y., Larouche, A., Brossier, B., Blarquez, O., Ali, A.A., 2013. Multi-millennial fire frequency and tree abundance differ between xeric and mesic boreal forests in central Canada. J. Ecol. 101, 356-367. https://doi.org/10.1111/1365-2745.12047.

Stevens-Rumann, C.S., Kemp, K.B., Higuera, P.E., Harvey, B.J., Rother, M.T. Donato, D.C., Morgan, P., Veblen, T.T., Lloret, F., 2018. Evidence for declining forest resilience to wildfires under climate change. Ecol. Lett. 21, 243-252. https://doi.org/10.1111/ele.12889.

Stocks, B.J., Fosberg, M.A., Lynham, T.J., Mearns, L., Wotton, B.M., Yang, Q., Jin, J.-Z., Lawrence, K., Hartley, G.R., Mason, J.A., McKenney, D.W., 1998. Climate change and forest fire potential in Russian and canadian boreal forests. Climatic Change 38, 1-13. https://doi.org/10.1023/A:1005306001055.

Stocks, B.J., Mason, J.A., Todd, J.B., Bosch, E.M., Wotton, B.M., Amiro, B.D., Flannigan, M.D., Hirsch, K.G., Logan, K.A., Martell, D.L., Skinner, W.R., 2003. Large forest fires in Canada, 1959-1997. J. Geophys. Res. 108, FFR5.1-FFR5.12. https://doi.org/10.1029/2001JD000484.

Stokes, M.A., Smiley, T.L., 1968. Introduction to tree-ring dating. In: University of Chicago Press. University of Chicago Press, Chicago, IL.

Swain, A.M., 1973. A history of fire and vegetation in northeastern Minnesota as recorded in lake sediments. Quat. Res. The Ecological Role of Fire in Natural Conifer Forests of Western and Northern America 3, 383-396. https://doi.org/ 10.1016/0033-5894(73)90004-5.

Swetnam, T.W., Allen, C.D., Betancourt, J.L., 1999. Applied historical ecology: using the past to manage for the future. Ecol. Appl. 9, 1189-1206. https://doi.org/10. $2307 / 2641390$.

Terrier, A., de Groot, W.J., Girardin, M.P., Bergeron, Y., 2014. Dynamics of moisture content in spruce-feather moss and spruce-Sphagnum organic layers during an extreme fire season and implications for future depths of burn in Clay Belt black spruce forests. Int. J. Wildland Fire 23, 490-502. https://doi.org/10.1071/ WF13133.

Tinner, W., Hubschmid, P., Wehrli, M., Ammann, B., Conedera, M., 2001. Long-term forest fire ecology and dynamics in southern Switzerland. J. Ecol. 87, 273-289. https://doi.org/10.1046/j.1365-2745.1999.00346.x.

Tolonen, M., 1985. Palaeoecological record of local fire history from a peat deposit in SW Finland. Ann. Bot. Fenn. 22, 15-29. http://www.jstor.org/stable/23725288.

Waito, J., Girardin, M.P., Tardif, J.C., Conciatori, F., Bergeron, Y., Ali, A.A., 2018. Recent fire activity in the boreal eastern interior of North America is below that of the past 2000 yr. Ecosphere (in press).

Waito, J., Girardin, M.P., Tardif, J.C., Hély, C., Blarquez, O., Ali, A.A., 2015. Fire and climate: using the past to predict the future. In: Peh, Kelvin S.-H. Corlett, Richard T., Bergeron, Yves (Eds.), Handbook of Forest Ecology. Oxford, UK, pp. 476-487.

Wallenius, T., Kuuluvainen, T., Heikkilä, Lindholm, 2015. Spatial tree age structure and fire history in two old-growth forests in eastern Fennoscandia. Silva Fenn. 185-199. https://doi.org/10.14214/sf.557.

Whitlock, C., Larsen, C., 2002. Charcoal as a fire proxy. In: Smol, J.P., Birks, H.J.B., Last, W.M., Bradley, R.S., Alverson, K. (Eds.), Tracking Environmental Change Using Lake Sediments, Developments in Paleoenvironmental Research. Kluwer Academic Publishers, Dordrecht, The Netherlands, pp. 75-97. https://doi.org 10.1007/0-306-47668-1 5.

Whitlock, C., Millspaugh, S.H., 1996. Testing the assumptions of fire-history studies: an examination of modern charcoal accumulation in Yellowstone National Park, USA. Holocene 6, 7-15. https://doi.org/10.1177/095968369600600102. 